\title{
FROM THEORIES OF EFFICIENCY TO SPECIFICATIONS FOR ASSESSMENT OF THE EFFICIENCY OF MUNICIPAL SERVICES
}

\section{AGNIESZKA KWARCIŃSKA}

University of Szczecin, POLAND

e-mail: agnieszka.kwarcinska@wzieu.pl

RECEIVED
ACCEPTED
JEL
CLASSIFICATION

KEYWORDS

ABSTRACT
9 Maj 2018

13 September 2018

$\mathrm{A} 13, \mathrm{D} 61, \mathrm{H} 44$

efficiency, efficiency of municipal services, the features of municipal services

This article presents issues related to assessment of the efficiency of municipal services from the point of view of both theories of efficiency available in literature and the specific features of municipal services. Many attributes of municipal services differ from those of other services. Therefore, to consider municipal services from the perspective of efficiency, the need to adopt separate assessment criteria arises. This article aims to present the prevailing trends in research regarding the assessment of the efficiency of municipal services within the context of theoretical considerations available in economic literature.

\section{Introduction}

Contemporary management, both in global, national, regional, and microeconomic terms, takes place in face of the growing impact of digitization processes and the need to verify both management solutions applied thus far and the effects generated thereby. In development programs and strategies, efficiency (alongside knowledge and innovation) is of particular importance. According to many researchers, efficient management helps to strengthen 
enterprise competitiveness and, as a result, accelerate the socio-economic development or regions and countries. As such, the search for solutions for increasing efficiency has in recent years gained fundamental significance, both in terms of economic theory and practical applications for contemporary management science. However, the complex and multifaceted nature of the phenomena shaping the increased efficiency of enterprises, including in the areas of management and motivation, has resulted in the need to search for optimal methods for assessing the implementation of such phenomena.

Efficiency is most often considered from an economic perspective and with regard to a wide range of management issues. Although the connotation of the term 'efficiency' is ever positive, the concept must nonetheless be examined in a certain amount of detail. This is also the case with regard to the efficiency of municipal services, for which it is reasonable to consider various aspects of efficiency and to apply specific assessment criteria.

This article aims to present the prevailing trends in research regarding the assessment of the efficiency of municipal services within the context of theoretical considerations available in economic literature.

\section{Efficiency - Theoretical apppoach}

Efficiency is a term frequently used in various contexts. It is often equated with an economic calculations, i.e. accounting for the effects obtained in relation to the inputs necessary to obtain such effects. Efficiency may be analysed on the scale of an entire economy, whether in macroeconomic or microeconomic terms, with references to such aspects as individual business entities, organizational units, processes, projects, products, and services.

The most general determination of efficiency focuses on resources which are available yet limited and their use to satisfy broadly understood human needs (Mankiw, Taylor, 2009, p. 35; Czarny, 2011, p. 23). In this sense of efficiency, satisfaction of needs falls in the effects category, whereas the available resources fall in the inputs category. As such, efficiency is considered as the full utilisation of resources to obtain the greatest possible benefit. The lack of waste is also a significant issue in the consideration of efficiency, as noted by P.A. Samuelson and W.D. Nordhaus (2000, p. 61). Limited resources necessitate rational management in a manner which allows for the achievement of the best possible set of benefits. The reasonable allocation of such resources - without loss determines the most beneficial satisfaction of needs. The condition regarding waste takes into account the efficient and economical management of specific resources, i.e. the distribution and deployment thereof, according to the given process, to achieve the greatest possible amount of good to satisfy needs.

Effective allocation - in the sense of the Pareto principle - means a state in which an increase in benefits for one person may only be achieved by reducing the benefits for another person. Thus, it is not possible to reallocate resources to improve one person's situation without harming another. This manifestation of efficiency is often taken into account by economists (Brümmerhoff, 2007, p. 42; Pindyck, Rubinfeld, 2009, p. 766; Varian, Buchegger, 2007, p. 17; Case, Fair, 2007, p. 14). It refers not only to such problems as scarce resources and the economic viability of management thereof, but also to the necessity of the selective allocation of such resources. This also provides a specific foundation for all economic considerations regarding the rationalness of applied and implemented economic activities.

Both the analytical context and the scope of application of efficiency determine its definition and assessment. For example, the efficiency of an organization, determined primarily by the results of its activities, and additionally considered as its ability to implement a strategy and to achieve certain goals (Skrzypek, 2002, p. 190), is also subject to extended and multifaceted evaluation. R.S. Kaplan and D.P. Norton (2001, p. 27) consider the efficiency 
of an organization in terms of four perspectives associated that organization's strategy: the financial perspective, which measures the current financial success of the organization as a business; the client perspective, indicating the sources of such success, including market position and customer satisfaction; internal processes, regarding processes taking place within the organization; and development, determining the ability of the organization to further change and grow, on which the future success of the organization depends. In contrast, G.A. Rummel and A.P. Brache (2000, pp. 54-55) analyse three interdependent levels of efficiency: organization, process, and employee.

In turn, the efficiency of planned investment activities and projects is analysed primarily in the context of the financial benefits (Pastusiak, 2009, p. 113; Wrzosek, 2008, p. 13). The economic viability of such is determined by obtaining financial benefits of greater value than the expenses incurred.

In the subject literature, the efficiency of a product is also considered through the prism of the relationship between expenditures and obtained effects (Storoniak-Palczak, Szwajca, 2013, p. 47). An efficient product is one in whose effects are greater than the amount of expenditures associated with the production thereof. The inefficiency of a product is demonstrated by the excess expenditure required to product said product in relation to the effects generated thereby.

In summary, efficiency which determines the rationales of economic activity remains a generally useful economic category. It may be analysed in various contexts and interpreted in many aspects. The fundamental rule of obtaining greater effects than the amount of inputs necessary to achieve such effects remains unchanged. Accepting principled considerations on the subject of efficiency as a basis, the efficiency of municipal services may be discussed. Assessment of the efficiency of this particular type of service requires specific treatment.

\section{The features of municipal services as the primary determinantits of the speciifications for assessment of the efficiency thereof}

The necessity to apply a special approach to the assessment of the efficiency of municipal services results primarily from the specific features of municipal services, which, in addition to social and administrative services, constitute public services (Dylewski, Filipiak, 2005, p. 459). The collective needs of a specific community are the foundation for the provision of municipal services. The satisfaction of such needs in accordance with Polish law is the responsibility of the municipality (The Act of March 8, 1990). The principles and forms of implementation of such responsibilities are also regulated by law and are related to municipal management (The Act of December 20, 1996). In turn, this includes responsibilities which are by nature public utilities, aimed at the current and continuous satisfaction of the collective needs of the population through the provision of publicly available services. Legal provisions both confirm the importance of municipal services and set the basic conditions for implementation thereof, i.e. the provision of municipal services in an ongoing and uninterrupted manner, ensuring universal access thereto.

In relation to municipal responsibility, municipal services constitute a set of services, including: supplying water, disposing of sewage, collecting municipal waste, maintaining landfills and disposing of municipal waste, maintaining sanitary facilities, maintaining general cleanliness and order, supplying heat, electricity, and gas, providing local public transport, and providing public housing. The aforementioned services are characterized by

${ }^{1}$ More on the determinants of the efficiency of municipal services in Kwarcińska (2011), pp. 133-142. 
a high degree of significance for the function of each local community. The source of the demand for such services are needs which may be considered as basic (obligatory) needs. The occurrence of such needs incurs the necessity to swiftly and effectively satisfy them. The efficiency of their satisfaction determines the fundamental conditions of existence. This is why it is so important both that services be provided in an ongoing and uninterrupted fashion to meet these needs. The related problem of maintaining continuity in the provision of municipal services is in turn an extremely important determinant of their efficiency.

However, the most important condition which distinguishes municipal services is their universal availability. In simplified terms, this is understood primarily as the easy, unencumbered access of each and every member of the local community to such services. However, detailed consideration of such requires consideration of various aspects of availability (Babis et al., 2000, p. 13; Kwarciński, 2009, p. 66). The first such aspect, economics, refers primarily to the price paid for the service. The second aspect, time, may be analysed as the waiting period for the service or as the service completion time. The next aspect, space, should take into account, for example, the geographical distribution of access to a municipal service (e.g. connection to a water supply or sewage network, or the distance to waste collection facilities). The last aspect of accessibility, information, should be treated as access to information on specific municipal services, on the prices, and means of provision thereof, and on the entities providing such services.

From the perspective of the importance of the accessibility criterion, the provision of municipal services assumes supremacy in the implementation of social responsibilities. The primary corollary of this is the subordination of economic concerns, including economic efficiency. Thus also follows the premise for specific recognition and analysis of the efficiency of municipal services.

Apart from the primary features distinguishing municipal services, one should also indicate several more significant features, as these also significantly determine the need for a specific assessment of the efficiency of municipal services. Often, the provision of municipal services is associated with great dependence on technical infrastructure, of which both the creation and maintenance requires appropriate expenditures. In addition, the product delivered as part of municipal services is often homogeneous, standardised, and without substitutes. Related to this issue are demand-side market limitations concerning changes in the service provider and the given standard of service, and on the supply side, the occurrence of so-called local monopolies and applicable requirements, including those of legal origin, in relation to the quality of specific services. In addition, municipal services are provided to a specific local community with the appropriate features, age structure, property resources, spatial distribution, etc. This means that service providers do not choose a client but provide a service to everyone who belongs to a given community.

When characterizing municipal services, one should pay attention to specific legal regulations referring to the markets for specific types of municipal services, such as the imposition of maximum prices, and additionally to entities which provide services where there appear specific requirements with regard to both service providers and to services, which must fulfil certain established quality standards. Undoubtedly, all regulations have their own justifications, simultaneously affecting the efficiency of municipal services.

In summary, the features of municipal services indicate the determinants for the specifications for assessment of the efficiency of such services. Among them, the most important can be considered as: the ongoing and uninterrupted nature of municipal services, the economic, temporal, spatial, and informational accessibility of municipal services, the supremacy of social responsibilities with regard to implementation, dependence on 
technical infrastructure, the lack of available substitutes, the existence of local monopolies, legal regulations concerning the markets for municipal services, legal regulations concerning entities providing municipal services, legal regulations concerning specific municipal services. The presented characteristics of municipal services warrant a particular approach to assessment of the efficiency of such services, which in the broadest sense should take into account both economic and non-economic aspects.

\section{Basic aspects and criteria for assessment of the efficiency of municipal services}

Due to the specificity of municipal services, the assessment of their efficiency should not be focused solely on the classic economic approach. Even the most important social and organisational issues confirm that such a multi-aspectual approach to the concept of efficiency is justified. It may be noted that in the case of providing municipal services, there are three main groups of entities. First are municipalities, which are legally obliged to satisfy the collective needs of their population through implementation of their responsibilities. Municipalities are primarily the initiators and organisers of municipal services. They are responsible for ensuring the availability of such services. They decide on the methods of implementation and financing of such services, creating specific conditions. Municipalities also often participate in investment processes.

The second group of entities are enterprises which directly provide municipal services. They assume the burden associated with the provision of services. They act as a contractor performing specific activities in the field of municipal management, assuming the risk of operating a business, with the awareness of all rights, limitations, and both economic and non-economic liabilities. As all other business entities, they operate in a specific environment, accept all external and internal conditions, and achieve their goals. By engaging their resources, enterprises organize the process of providing municipal services and remain in direct contact with their stakeholders, including clients. Their image is based on the proper implementation of municipal services in the consciousness of the entire local community. Thus, enterprises represent the nexus of municipal responsibility and the reporting of collective needs by communities.

The last group are members of a community who are connected by a common area of residence and who require specific, obligatory needs. They play a dual role. On the one hand, they initiate the necessity of a municipal service by reporting the need for such, and on the other hand they are the consumers of municipal services. The conditions for satisfying such needs are a set of specific postulates regarding the nature of municipal services, whereas satisfaction levels are the subjective feelings of consumers. At the same time, consumer responses may concern both the actions of the municipality in fulfilment of its legal obligations regarding the provision of municipal services as well as the broadly defined activity of enterprises providing such services.

Due to the presented involvement three groups of entities in the process of providing municipal services, it seems reasonable to take into account economic and non-economic aspects, including primarily organizational and social aspects, in analysing the efficiency of municipal services. In each of these scenarios, it is important to achieve greater results in relation to inputs. It should be emphasized, however, that in the case of the efficiency of municipal services in an economic context, both results and inputs are more easily measurable than social and organisational factors. This is often not a simple calculation, especially when subjective and qualitative measures arise. This issue also concerns another very complex issue related to the selection of methods, tools and specific measures to assess the efficiency of individual municipal services and requires separate study. 
Meanwhile, focusing on the basic features of municipal services and taking into account the need to conduct multi-aspectual assessment of the efficiency of municipal services, one may indicate the fundamental criteria for such assessment. These are:

- ongoing satisfaction of the collective needs of the population,

- uninterrupted satisfaction of the needs of the population,

- widespread availability in economic terms,

- widespread availability in spatial terms,

- widespread availability in temporal terms,

- widespread availability in informational terms,

The presented criteria do not exclude and do not diminish the importance of applying conventionally and widely used criteria for efficiency assessment. Instead the above criteria are complementary and emphasise the specifics of municipal services. Their consideration allows for more precise analysis and evaluation of the efficiency of such services.

\section{Conclusions}

Efficiency is a category that is referenced very often and in various contexts. Its economic dimension, based on the basic principle of obtaining greater effects in relation to the incurred expenditures, also translates into a noneconomic dimension. Accounting for non-economic aspects of efficiency is not simple, but is important and justified when assessing the efficiency of municipal services in particular. The specificity of these services implies the need for broad recognition of issues of efficiency and creates the necessity of applying differentiated research instruments. The assessment of the efficiency of municipal services should be preceded by identification of the determinants of such efficiency. This is the basis for identifying the main aspects of efficiency, which in the case of municipal services include, in addition to the economic approach, organizational and social dimensions.

\section{References}

Babis, H., Czaplewski, R., Panasiuk, A., Sondej, T. (2000). Problemy regulacji dostępności usług pocztowych o charakterze powszechnym. Szczecin: Wydawnictwo Naukowe Uniwersytetu Szczecińskiego.

Brümmerhoff, D. (2007). Finanzwissenschaf. München, Vienna: Oldenburg Verlag.

Case, K.E., Fair, R.C. (2007). Principles of Microeconomics. Pearson Education.

Czarny, B. (2011). Podstawy ekonomii. Warszawa: Polskie Wydawnictwo Ekonomiczne.

Dylewski, M., Filipiak, B. (2005). Usługi publiczne. In: S. Flejterski, A. Panasiuk, J. Perenc, G. Rosa (eds.), Współczesna ekonomika usług. Warszawa: Wydawnictwo Naukowe PWN.

Kaplan, R.S., Norton, D.P. (2001). Strategiczna karta wyników. Jak przełożyć strategię na działanie. Warszawa: Wydawnictwo Naukowe PWN.

Kwarcińska, A. (2011). Determinanty efektywności usług komunalnych. Zeszyty Naukowe Uniwersytetu Szczecińskiego, 682. Ekonomiczne Problemy Usług, 76.

Kwarciński, T. (2009). Dostępność transportowa - podejście teoretyczne i praktyczne. Zeszyty Naukowe Uniwersytetu Szczecińskiego. Ekonomiczne Problemy Usług, 33.

Mankiw, N.G., Taylor, M.P. (2009). Mikroekonomia. Warszawa: Polskie Wydawnictwo Ekonomiczne.

Pastusiak, R. (2009). Ocena efektywności inwestycji. Warszawa: CeDeWu.

Pindyck, R., Rubinfeld, D. (2009). Mikroökonomie. München: Pearson Studium.

Rummel, G.A., Brache, A.P. (2000). Podnoszenie efektywności organizacji. Warszawa: Polskie Wydawnictwo Ekonomiczne. 
Samuelson, P.A., Nordhaus, W.D. (2000). Ekonomia, vol. 1. Warszawa: Wydawnictwo Naukowe PWN.

Skrzypek, E. (2002). Jakość i efektywność. Lublin: Wydawnictwo Uniwersytetu Marii Curie-Skłodowskiej.

Storoniak-Palczak, G., Szwajca, D. (2013). Skuteczność produktu. Zeszyty Naukowe Politechniki Śląskiej, Seria Organizacja i Zarządzanie, 1898. Retrieved from: http://yadda.icm.edu.pl/yadda/element/bwmeta1.element.baztech-9feb5f16-16ba-492ba8cf-74afe24a56dd/c/Storoniak2_ZNO (16.02.2018).

The Act of December 20, 1996 on municipal management. OJ 2017, item 827.

The Act of March 8, 1990 on municipal self-government. OJ 1990, no. 16m item 95

Varian, H.R., Buchegger, R. (2007). Grundzüge der Mikroökonomik. München: Oldenbourg Wissenschaftsverlag.

Wrzosek, S. (ed.) (2008). Ocena efektywności inwestycji. Wrocław: Wydawnictwo Uniwersytetu Ekonomicznego we Wrocławiu.

Cite this anticle aS: Kwarcińska, A. (2018). From theories of efficiency to specifications for assessment of the efficiency of municipal services. European Journal of Service Management, 3 (27/1), 127-133. DOI: 10.18276/ejsm.2018.27/1-15. 